\title{
Impact of Petroleum Product on the Soil around Automobile Workshops in Osun State
}

\author{
${ }^{1}$ Farombi A. G,${ }^{2}$ Adebayo. O. R, ${ }^{3}$ Oyekanmi A. M \\ ${ }^{I}$ Science Laboratory Technology Department, Faculty of Science, Osun State Polytechnic Iree, Nigeria. \\ ${ }^{2}$ Applied Science Department, Faculty Of Science, Osun State Polytechnic, Iree, Nigeria.
}

\begin{abstract}
Effects of petroleum product were investigated on the soil samples in automobile engineering workshops at eight different points in osun state. Composite samples were taken at two depths of $0-15 \mathrm{~cm}$ and $15-30 \mathrm{~cm}$, therefore a total of sixteen samples were considered. From the properties determined, it was shown by the result that the soil samples were acidic. The $P^{H}$ ranged from $4.61-6.25$ and $4.30-7.45$ EC,49.40-8500 $(\mu / \mathrm{cm})$ and $40.20-357(\mu \mathrm{s} / \mathrm{cm})^{2}$ CEC, 1.00-168.25(meq/100g) and 2.10- 17.65 (meq/100g), TOC,0.83-40.22\% and $0.10-3.75 \%, S A R, 0.10-0.98$ and $0.12-0.60$, Total nitrogen $0.05-0.20 \%$ and $0.02-0.64 \%$. The concentrations of heavy metals were also determined and the result indicates the favourable natural mechanism of high uptake of the metals.
\end{abstract}

\section{Introduction.}

Industrialization, technology, economic growth, improved life style, population growth and environmental pollution are interwoven. (Odiete, 1999) Heavy metal contamination and petroleum hydrocarbon emission today have great ecological significant due to their toxicity and accumulation. In recent years, the occurrences of metal contamination especially heavy metal in excess of natural load have become problem of increasing concern. This situation has arisen as a result of rapid growth in population, increase urbanization expansion of industrial activities, exploration and exploitation of natural resources and agricultural practices as well as lack of environmental regulations (Biney et al, 1994). Heavy metals are associated with various soil components in different ways and these associations determine their mobility and availability (Kabata- pendias and Pendias 1992, Sigh, 1997; Ahumada et al 1999). This soil texture (clay content), organic matter and Fe-Mn oxides have been found to be most important properties and component influencing the ability and biological update of heavy metals (Iyengar et al, 1981; Narwal and Sinhyg 1988; Ma and Rao, 1997; Karsczewska et al, 1998.)

Heavy metals, contrary to most pollutants (e.g. petroleum hydrocarbon) are not biodegradable and undergo a global ecological cycle (Nurberg, 1984). Heavy metals pollution can affect all environment but their effects are long lasting in solids due to the relatively strong absorption of many metals onto humid and clay colloids in soil. (Alloway and Arye, 1994). The duration of contamination may be hundreds and thousands of years in many cases, depending on the soil type and physicochemical parameters. Unlike organic pollutants which will ultimately be decomposed, metals will remain atoms although their speciation may change with time as the organic molecules binding them decompose or soil condition changes (Alloway and Arye, 1994).

Some heavy metals such as $\mathrm{Zn}, \mathrm{Cu}, \mathrm{Mn}$ and $\mathrm{Fe}$ are essential for the growth and well being of living organisms. However, they are likely to show toxic effect when organisms are exposed to levels higher than normal, such as $\mathrm{Pb}, \mathrm{Hg}$, and $\mathrm{Cd}$ are not essential for metabolic activities and exhibit toxic properties (Binery et al, 1994). Heavy metals are toxic to animal and plants, although plants and animals vary widely in sensitivity. (Clark, 1982; Odiete, 1999). Hence, abnormally high concentrations of metals create concern to the normal functioning of the ecosystem.

\section{Sample collection and preparation.}

\section{Materials And Method.}

Soil samples were collected from eight different points of automobile engineering workshop within olorunda local government of osun state.

Composite samples were taken at two depths $0-15 \mathrm{~cm}$ and $15-30 \mathrm{~cm}$. A total of 16 samples were considered. The samples were air dried, sieved through $2 \mathrm{~mm}$ mesh size and stored at $4^{0} \mathrm{c}$ until the analysis were carried out.

The soil $\mathrm{P}^{\mathrm{H}}$ was determined in soil suspension (1:2.5 soil water ration) using a glass electrode $\mathrm{p}^{\mathrm{H}}$ meter. Particule size distribution were determined using the pipette method of kilmer and Alexander (1949). Relative properties of sand, silt and clay were estimated.From dried sample Soil textures were then determined with the aid of a textural triangle. Cation exchange capacity of the soil samples was determined as the sum of basic cations extracted with neutral IM NH 4 and extractable acidity (Recumjk,1995). The $\mathrm{NH}_{4}$-extracted $\mathrm{Na}^{+}, \mathrm{k}^{+}$, 
$\mathrm{Mg}^{2+}$ were determined by flame Photometry and $\mathrm{Ca}^{2+}$ by atomic absorption spectrophotometer. The electrical conductivity was determined on the filterate obtained filtering the suspension used for $\mathrm{pH}$ measurement with the aid of conductivity meter. Total organic carbon of the sample was determined by using Bamgbose et al, 1999 method. Ammonium nitrogen was determined by nesslenzation. Nitrite-Nitrogen was determined by Greissllosvary method using napthylamine and sulphanlic acid. Nitrate nitrogen was determined by the phenoldisulphonic acid nethod. The total phosphorus contents of the soil was determined by $\mathrm{H}_{2} \mathrm{SO}_{4}-\mathrm{HC}_{4}$ digestion and analyzed through the wetanabe and olsen ascorbic acid modification of the molybdate blue method (Olsen and Sommer, 1982). The sample solution was analyzed for $\mathrm{Cu}, \mathrm{Zn}, \mathrm{Cr}, \mathrm{Ni}, \mathrm{Pb}, \mathrm{Cd}$ and $\mathrm{Mn}$ using air - acetylene flame atomic absorption spectrophotometer (AAS).

\section{Result and Discussion.}

Table 1 reports the particle size and some general characteristics namely; percentage organic carbon, conductivity, cation exchange capacity (CEC), sodium adsorption ratio (SAR) of the soils examined. At $p>0.05$ there is a significant spatial variation in physicochemical characteristics of the soil samples examined. The particle size distribution was predominantly clay fraction in both surface and subsoil. The $\mathrm{P}^{\mathrm{H}}, \mathrm{CEC}^{\mathrm{c}}$, Organic carbon and carbonate are among several components of soil that affect the availability, retention and mobility of metals with increasing $\mathrm{pH}$ (Hanna, 1998). The $\mathrm{pH}$ of the examined soil indicated high tendency of metal availability. Hence, this is a favorable natural mechanism of high uptake of the metal. $\mathrm{pH}$ values were predominantly higher in the $15-30 \mathrm{~cm}$ depth except for few sites that have $\mathrm{pH}$ values higher than those of top soils. Result showed high total organic carbon (TOC) at all sites. The TOC values were abnormally high in some sites like, sites $5 \mathrm{~A}$ and $6 \mathrm{~A}$ have TOC value of $37.85 \% \&$, 40.22 respectively. The abnormally high TOC content of these soil samples could probably be due to the contribution of organic carbon from petroleum products used for the engines in it workshop. However, about $82 \%$ of the top soil samples had TOC value less than 3\%. Electrical conductivity (EC) is used as a means of appraising soil salinity, EC increases with soluble salt content of soil. The EC value of $4000 \mu \mathrm{S} / \mathrm{cm}$ which correspond to an osmotic pressure of 3-5 atmosphere in soil at field capacity, is generally accepted (Odu et al, 1985). The mean levels of electrical conductivity of the soil examined are high due to the contributions of elevated level in EC in the heavily impacted soils, for example siteS 5A, and 6A have EC value of $8500 . \mu \mathrm{s} / \mathrm{cm}$, and $1126 \mu \mathrm{s} / \mathrm{cm}$ respectively for top soil, the EC values are greater than the acceptable limit. The exceptionally high conductivity of these site could be attributed to the components of some used materials in the workshop for example the engine oil, brake oil, and other petroleum products. Above all, $69 \%$ of the examined soil have EC levels less than $200 \mu \mathrm{s} / \mathrm{cm}$ and with value corresponding to that of typical Niger Delta soil (Isiri, mah 1987). Cation exchange capacity (CEC) is the amount of exchangeable cation per unit weight of clay soil that plays important role in soil fertility. Nigeria soils with cation content of $2 \mathrm{meq} / 100 \mathrm{~g}$ soils are considered for calcium and magnesium while $0.2 \mathrm{meq} / 100 \mathrm{~g}$ soils and above are adequate for potassium ion Codu et al, 1985). 50\% of the soil examined has CEC below $3.00 \mathrm{meq} / 100_{\mathrm{g}}$. Sites with high TOC value showed corresponding high cation exchange capacity. Cation exchange capacity showed positive correlation with TOC $(r=0.828: p=0.07)$. Suggesting that the binding sites on the organic matter, such as negatively charged humic acids contribute to the retention of cation in the soil (Abollino et al,2002). Table II showed the total metal concentration in the investigated soils. The acidic nature of the soil examined has favoured the mobilization of heavy metals $(\mathrm{Cu}, \mathrm{Cr}, \mathrm{Zn}, \mathrm{Ni} \mathrm{Pb}, \mathrm{Cd}, \mathrm{Mn})$ that are manifested in low abundance. (Bhattacharya et,al 2002). The examined soil can be considered unpolluted; since their concentration fitted Cu. According to reviews by Hindsay, 1979 ; Kabata - Pendias and Pendias, 1992 and Alloway 1995, normal concentration ranges of these metals in soils are $0.01-0.7 \mathrm{mgkg}^{-1}$ for $\mathrm{Cd} ; 1-1,000 \mathrm{mg}$ $\mathrm{kg}^{-1}$ for $\mathrm{Cr}, 2-250 \mathrm{mgg}^{-1}$ for $\mathrm{Cu}, 0.4-1,000 \mathrm{mgkg}^{-1}$ for $\mathrm{Ni} ; 2-200 \mathrm{mkg}^{-1}$ for $\mathrm{Pb}$, and $1-900 \mathrm{mg} \mathrm{kg}^{-1}$ for $\mathrm{zn}$. The concentrations of cadmium in the topsoil exceed at the upper limit except for site 2 . The concentration of copper, chromium, zinc, nickel lead, cadmium and manganese were higher in the soil than the subsoil except sites. The concentration of the of heavy metals reported in this study were by lower compared to earlier reports for contaminated sites. (Helmissar, et al. 1995 Ma and Rao 1997, Bangbose et, al. 1999, Rocks Zyk and szerzen, 1998, Kabala and Sigh 2001). The concentration of nicke and chromium reported in this study are comparable with levels. Reported by lavado et,al. Ma and Rao (1997) and are higher than value reported for soil around smelter complex in Poland . copper, chromium, and nicked showed positive significant correlation. This can be explained by chemical similarity and common source. Copper, cadmium and manganse are positively correlated with total organic carbon (TOC) suggesting that these metals are attached to the binding sites on organic matter, such as the negatively correlated humic acids. This contributes to the retention of these metal cations (Abollino et al 2002). CEC is not related to any of the metals concentration except cadmium, probably because such metals are mainly bound to the soil matrix and are present in the exchangeable forms only in very low percentage (Abollino et, al, 2002). The positive correlation of cadmium with cation exchange capacity implied that non- specific adsorption controls cadmium adsorption. 


\section{Conclusion}

The data presented here indicated that the soil samples examined were acidic.This showed a high tendency of metal availability. Heavy metal contaminations of the impacted soils were primarily restricted to the surface horizons. The distribution Patten of heavy metals was in the following order $\mathrm{Mn}>\mathrm{Ni}>\mathrm{Zn}>\mathrm{Cr}>\mathrm{Pb}>$ $\mathrm{Cu}>\mathrm{Cd}$ and $\mathrm{Mn}>\mathrm{Zn}>\mathrm{Ni}>\mathrm{Pb}>\mathrm{Cr}>\mathrm{Cu}>\mathrm{Cd}$ for the top and su soil respectively. The result also indicated that except for cadmium and lead, the levels recorded did not exceed background levels for unpolluted soil. This study revealed that the concentration of the heavy metals have increased in several folds when compared to the baseline levels of these metals recorded before the usage as mechanic workshop. However, metal build up is a gradual process, farmlands, fishing ponds and water bodies around these facilities will be at risk over time if a monitoring programme is not put in place.

Total heavy metal concentration to a great extent measures the degree of contamination. There is a large consensus among the scientific community to believe that the risks for living organism associated to the presence of heavy metal in our environment is determined for a large part by the solubility of the various heavy metal bearing phases present rather than by the total elemental concentration. As a consequence, knowledge of the total heavy metal in soils provided only limited information, as this does not show how strongly the metal is bound to soil constituents. By indentifying those heavy metal bearing phases and their solubility in a aqueous fluids, one can infer the potential and bioavailability of toxic metal.

\section{References}

[1]. Abollino, O, Aceto, M., Malandrino M., Menstati E. AND Petrella F. (2002).Heavy metal in agricultural soil from Piedmont Italy. Distribution, Speciation and chemometric data treatment. Chemosphere 49:545-557.

[2]. Ahumada .I, J Mendoza and L. Ascar (1999)Sequential extraction of heavy metal in soils irrigated with wastewater. Communication in Soil Science and Plant Analysis: 30:1507-1519.

[3]. Alloway B.J.(1995): Heavy metal in soil, $2^{\text {nd }}$ edu. Wiley New York.

[4]. Alloway B.J. AND Ayre D.C. (1994): chemical principle of environmentalPollution.Publisher, Blackie London.

[5]. Bamgbose .O., Odukoya and T.O.A Arowolo (1999) Earthworm as bio-indication of metal pollution on dump site of Abeokuta City, Nigeria.

[6]. Bhattacharya, P., Mukherjee, A.B. Jacks J. and Nordqvist S.(2002). Metal contamination experimental studies on remediation. The Science of total Environment 290:165-180.

[7]. Biney C.A., A.T. Amuzu, D. Calamari, N. Kaba,. I.L nbome H Naeve, P.B.O Ochumba, O. Osibanjo, V. Radegonde and M.A.H Saad (1994) Review of Heavy metal p 30-60. In Calamari D. and h. Naeve (eds) Review ofpollution in Africa Aquatic Environment. FOA/CIFA Technical paper25.

[8]. Clark R.B. (1982). Biological effect of opil pollution.Water science and Technology 14, 1185-177.

[9]. Helmisaari H.S., J jorome, h Fritze, T. Nieminen, P. Palmgre, M. Salemaa and I. Vanha-Mamamma (1995) Copper in scoot pine forest around a heavy metal smelter in southwestern Finland. Water, Air, Soil Pollution: 85:1727-1732.

[10]. Isimirah N.O. (1987) Ann inventory of some chemical properties of selected surface soil of River State of Nigeria. In preceding of $15^{\text {th }}$ Annual Conferences Science Association of Nigeria Kaduna Pg 217-223.

[11]. Iyenegar S.S, Dc. Marten and W.P. Miller (1981)Distribution and plant availability of soil Zinc Fractions. Soil Science Society of America Journal 45:735-739.

[12]. Kabala. C.and B.R. Singh (2001). Fractionation and mobility of copper, lead, and zinc in soil profiles in the Vicinity of copper Smelter. Journal of Environmental Quality 30:345-492.

[13]. Kabala-Pendias, A., and H. Pendias(1992).Trace element in soil and plants $2^{\text {nd }}$ ed. CRC Press, Boca Raton, FL.

[14]. Karczewska., A, L Szerszen, and C. Kabala ( 1998)Forms of selected metals and their transformation in soils polluted by emission fromk copper smelters. Advanced Geo Ecology 31:705-7102.

[15]. Lindsay W.L. (1979): Chemical equilibria in soils. Wiley New York NY.

[16]. Ma, L.Q and G.N Rao (1997). Chemical fraction of cadmium, copper, nickel And zinc contaminated soils. Journal of Environmental Quality 26:259-264.

[17]. Narwal R.P and B.R Singh (1998). Effect of organic material or partitioning extractability and plant uptake of material in a alum shale soil. Water Air Soil pollution 103:405-421.

[18]. Nurnberg H.W (1984). The voltammetric approach metal Chemistry of natural water and atmospheric precipitation. Anal.Chem.Acta $164: 21$

[19]. Odiete W.O. (1999) Environmental Physiology of Animals and pollution, Diversified Resources Ltd, Lagos. Pg 204-218.

[20]. Odu C.T.I, L.C. Nwoboshi, O.F. Esuruoso and OJ.A Ogunwale (1985).

[21]. Environmental study (soils of vegetation) of the Nigerian Agip oil Company operation Areas. Proceeding of the international seminar on the Petroleum Industry and the Nigeria Environment. Port Harcourt pp 117- 123.

[22]. Olsen S.R. and L.E Sommer (1982).Phosphorus p403-430. In A.L page (ed).

[23]. Method of soil analysis. Part 2, 2n $2^{\text {nd }}$ Agron Monogr.9. ASA and SSA, Madison W.I. p 403-430.

[24]. Rockszyk E. and L. Szerezen (1998): Accumulation of heavy metals in arable Layer of soil in the protection zone of copper smelters.Rocz. Glebozn 39:135-156.

[25]. Singh B.R. (1997). Soil pollution and contamination P 279-299. In R. Lal (ed).

[26]. Method for assessment of soil degradation. C.R.C. Press, Boca Raton, FL. P 279-299.

[27]. Sposito G, L.J. Lund and AC Chang (1982) Trace metal chemistry in arid zone field soil amended with sewage sludge I. Fractionation of $\mathrm{Ni}, \mathrm{Cu}, \mathrm{Zn}, \mathrm{Cd}$ and $\mathrm{Pb}$ in solid phase.Soil Science Society of America Journal. 46:260- 246. 